ISBN 978-81-936279-5-2

12th International Conference on Business, Education, Humanities and Interdisciplinary Studies

(BEHIS-18)

Zagreb (Croatia) May 11-12, 2018

\title{
Marketing Mix Factors Affecting Mobile Phone Lines Manufacturing and Branding of the People's Republic of China
}

\author{
Ting Ting Chen and Dr. Watchara Yeesoontes
}

Graduate School of Business Administration, Kasem Bundit University, Bangkok, Thailand

\begin{abstract}
This research to study the loyalty of mobile phones and marketing mix factors affecting Mobile phone lines manufacturing and branding of the People's Republic of China. The scope of the study is marketing mix and brand loyalty. The study is quantitative in nature and taken 400 people of Bangkok for studying. The collected data is based on a questionnaire and data is analyzed by means of percentage, mean and $t$-test of Oneway Anova, and regression correlation. Most of respondents were Thai female aged of 26-30 years and having bachelor's Degrees and private business with the monthly income of 12,001-15,000 THB. According to study, respondents are using 2 phones brand of Huawei for last 13-24 months and the price of a phone is over 15,000 THB. Hypothesis testing Results show that the marketing mix factors affect the brand loyalty of the mobile phones which manufactured in China. The brand loyalty mean is moderate. The customers are loyal to the mobile phone brand and it indicates with very high level. It is recommended that mobile phone brand with friends or relatives for using.
\end{abstract}

Keywords: Mobile, China, Marketing Mix Factor, brand, loyalty etc.

\section{Introduction}

Currently, Thailand and China are trading more and more convenient trading. Thai people have the opportunity to use Chinese products in everyday life such as mobile phones. Chinese mobile phone brand is good quality. Various models easy to use, not as high as other brands. After the purchase is guaranteed. Easy to buy equipment for 2016. Mobile phone usage continues to grow. Due to the price factor, mobile phones are cheaper. There are also new technologies that will stimulate the market in terms of usage. Entertainment It is estimated that total mobile phone sales in 2016 are approximately 20 million units.

$12 \%$ the marketing factors in choosing new mobile phone The survey found that Consumers choose to buy mobile phones using the price of the handset as a factor. The low price of 10,000 baht is $72 \%$. Units priced at over 10,000 baht or more account for 28 percent of the market.

The secondary factor is the durability of use. Brand or brand is ranked No. 3, fourth most popular and aftersales service ranked fifth. Mobile phone usage continues to grow. Due to the price factor, mobile phones are cheaper. And there are new technologies. It has helped stimulate the market in terms of entertainment. It is estimated that the sales. The total number of mobile phones in 2016 will be approximately 20 million, growing by 12 percent. The market for new mobile phones that The survey found that Consumers choose to buy a mobile phone by using the price of the machine is a factor No. 1, with the price lower than 10,000 baht, the proportion is high. 72 percent Units priced at over 10,000 baht or more account for 28 percent of the market, followed by durability. Brand or Brand Ranked No. 3 Popularity No. 4 And after-sales service is \# 5.

However, the growth of the mobile phone market is attributable to two main groups of customers: the new handset group, representing 65\% 70 And the new customer group with the first mobile phone is 30-35\%. (NOL 
News Online: Siam Rath 3 January 2007) Bangkok Business has a telephone sales business. The number of mobile phones has increased and continues to grow.

This business is highly competitive in Bangkok. The main brands in China are Huawei oppo vivo and xiao $\mathrm{m}$ i that are popular and trusted by consumers.

Therefore, the study is interested in studying the marketing mix factors that affect the loyalty of mobile phones produced in China. This is a great way for mobile phone dealers to make and use Chinese brands as a guideline for creating the highest level of customer satisfaction. Loyalty to the brand. This will result in increased sales. And to create a good image.

\section{Objective of the Study}

1. To study loyal to the mobile phone manufacturer and brand of the PRC

2. To study the factors that influences the marketing mix, loyalty to handset manufacturers. and Brand Republic of China.

\section{The Hypothesis of the Study}

1. Personal factors affect different loyalty to mobile production and use.

The brand's PRC

2. Factors influencing the marketing mix, loyalty to mobile production and use.

Brand Republic of China.

\section{Scope of Study}

1. The content of the marketing mix. And brand loyalty ( To Brand the Loyalty).

2. The populations studied were guests. Select a sample of 400 people

3. The period of study between November BE2560 - February The BE 2561.

\section{Concept of formwork}

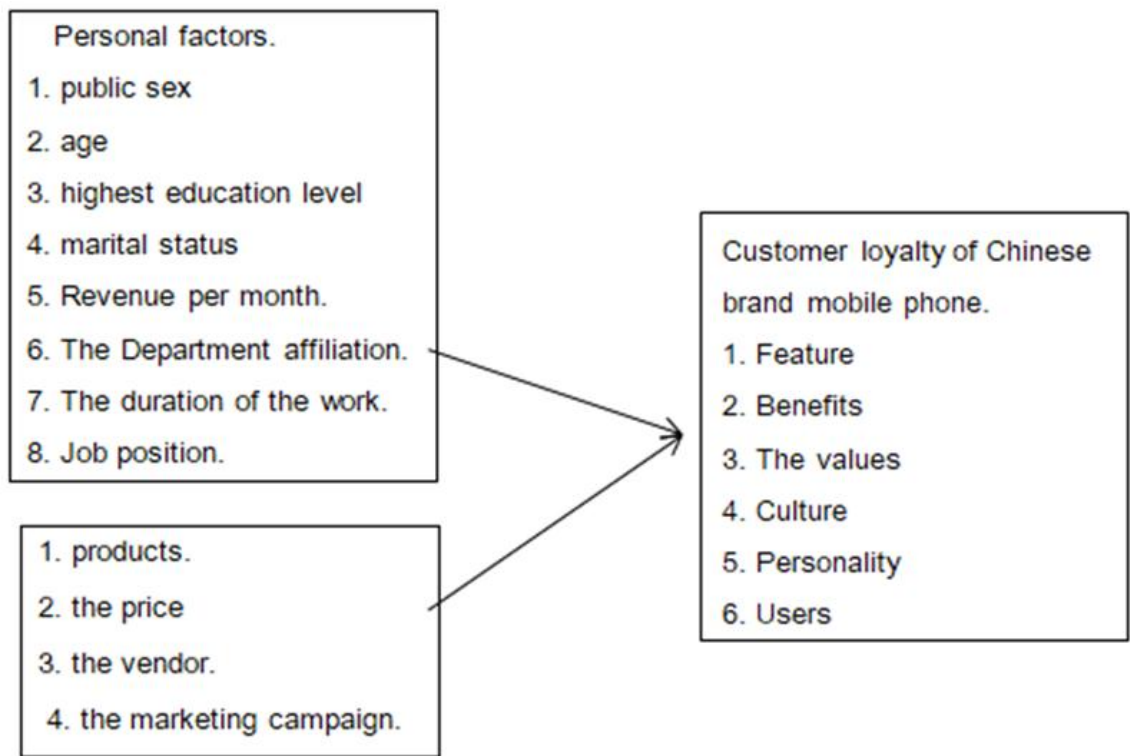




\section{Method}

Quantitative research and 400 questionnaires were used.

\section{Data Analysis}

The data obtained from the questionnaire were analyzed by computer program by means of Percentage, Mean, Anova and Regression.

\section{Research Result}

\section{- Personal Information}

The majority of respondents were female Thai nationals, aged 26-30 years, with a bachelor's degree. Private business Monthly income 12,001-15,000 Baht Currently using a phone 2 machines currently used Huawei brand phone the service life is 13-24 months and the purchase price is over 15,000 baht.

\section{Marketing Mix Factors}

- On the product side, we found that the overall mean of the market mix factor for mobile phones manufactured and branded by China. At the moderate level Customers are focused on mobile phones that produce and use Chinese brands at the highest level. The function is complete as needed.

- In terms of price, it is found that the overall mean of the market mix factor for Chinese manufactured and branded handsets. Very high Customers focus on mobile phones that are manufactured and branded by China. At most levels Is the price of the machine compared to the features.

- In terms of distribution, it was found that the overall mean of the market mix factor for Chinese manufactured and branded mobile phones. Very high Customers pay attention to the level of shopping. Is the customer service process at the service center

- Marketing promotion showed that the overall level of importance of the market mix factor for mobile phones manufactured and branded by China. At a moderate level, customers place importance on the level of shopping. Is there an ad when releasing new products or accessories

- $\quad$ Loyalty Brand Marketing Factors Affecting Loyalty to Cell Phones Manufactured and Branded in China Brand loyalty the mean was moderate. Brand loyalty is at the highest level. Is the customer loyal or loyal to the mobile phone brand used And at a very high level. It is recommended to use the brand you are using with your friends or relatives.

\section{The Hypothesis}

1. Personal factors affect different mobile loyalty and brand China's different. ANOVA statistical test found that customers using the company's mobile phone brand in China with sex, occupation, salary and the purchase price. Different affect the shopping is no different. For personal factors including age, education level. And lifetime different Affect the purchase different.

2. Assumption that marketing mix factors have influence the production and use of mobile brand of China. Test result by using the Regression statistics found that the marketing mix factors that influence the decision to buy a mobile phone. The product factor Brand issues. Influence the production and use of the mobile phone brand of China. Factor price the price of a suitability issues per machine, compared to the brand. Influence the decision to buy a mobile phone Distribution factor issues are sold throughout the country. Influence the decision to buy a mobile phone and a marketing campaign. The issue has an interesting campaign. Influence the decision to buy a mobile phone with a significant. 


\section{Discussion of Results}

The study of marketing mix factors towards loyalty of mobile phones made in China. Students are taken. Discussion on the result contains.

- Hypothesis 1 the different personal factors affect the loyal mobile phone production and the use of Chinese brands that differ. The test results using the ANOVA statistic found that age. Education and lifetime phone correspond to the research of supachart katcar (BE2552), a study of the relationship between customer satisfaction and customer loyalty and mobile phone. In Chiang Mai Province.

- Hypothesis 2: Market integration factors influence the decision to buy mobile phones produced in China. The results of the tests using regression showed that the product mix factor, product brand Influence the decision to buy a mobile phone at a moderate level. In line with research by Supachart Katcar (2009), the relationship between satisfaction and brand loyalty In Chiang Mai Factors Influencing Buying Behavior of Mobile Phones Brand story The price of the machine is comparable to the brand of the product. At the moderate level Distribution Issues Customer service at the service center. And convenience within the service center. At the highest and middle levels, respectively. And the promotion of advertising issues when advertising new products or accessories. At the highest level In line with Banchya's apimahachokpoking research (BE2556), marketing strategies have a direct influence on customer loyalty, in line with Sumali jantasen's (BE2556) research that marketing strategies affect brand loyalty. Products and prices are at a high level. And the distribution. The promotion of marketing was moderate.

\section{Suggestions from the Study}

The study about marketing mix factors affecting loyalty of mobile phones manufactured in the country pub Marketing Mix Factorslic. The State Council of people's Republic of China. The study recommends to the following benefits.

1. The products. Mobile Marketing Mix Factors phone manufacturer should emphasize production and branding to be acceptable to consumers.

2. The price, mobile phone manufacturers should set the price of the phone to suit the quality Marketing Mix Factorsy of mobile phone.

3. The distribution. Mobile phone manufacturers should emphasize comfort in service, including the service process customer source. Use of quality service.

4. Market promotion, mobile phone manufacturers. Should have advertising customers to know when they are out new products and various accessories.

\section{Suggestions for further Study}

1. The study of digital marketing that affects your decision to buy a mobile phone.

2. Education brands that have an impact on the satisfaction of customers who buy phones.

\section{References}

[1] Benchya apimahachokpokin (BE.2556). Service quality marketing strategies that influence the loyalty of modern retailers. Independent Study Master of Business Administration Management Lampang Rajabhat University.

[2] Supachart kadcar (BE.2552). Relationship between satisfaction and loyalty to the mobile phone brand. Chiang Mai University.

[3] Tosaporn mahamud (BE.2556). Marketing strategies that affect loyalty in the brand of food product purchased through department store counter. Kasembundit University,Bangkok

[4] Saree wongmonta (BE.2542). Bangkok: Teera Film and Cytec Co., Ltd.

Kotler \&Armstrong. (1999). Principles of Marketing, 8th ed., New Jersey:Prentice-Hall International, Inc 